\title{
Finding Antichrist: Apocalypticism in Nineteenth-Century Catholic England and the Writings of Frederick Faber
}

\begin{abstract}
The article discusses the apocalyptic beliefs of the nineteenth-century English Oratorian and devotional writer, Frederick Faber, though initially providing a context among earlier and contemporary English Catholic apocalyptic writers. It proceeds, by means of a consideration of Faber's conscious de-secularisation of language, to give an account of his identification of the elements of a transvalued contemporary popular concept of modernity as the signs of apocalyptic crisis. The article as a whole is intended to provide an aid to the perception and understanding of a pervasive apocalypticism in nineteenth-century English-speaking Catholicism.
\end{abstract}

\section{Introduction}

The present study is chiefly concerned with the apocalypticism expressed by one of the most noted of English spiritual writers, the Oxford convert and founder of the London Oratory, who remains most commonly referred to simply as Father Faber. In probing this unexplored and, indeed, little remarked on dimension of a well-known writer, it seems at least desirable firstly to indicate to the reader that Faber's apocalyptic beliefs are an unsurprising phenomenon in the English Catholicism of the nineteenth century, fitting into a substantial body of literature. This extended preliminary observation is intended also to provide a means of relating the positions taken on apocalyptic topics by Faber to those of his contemporaries.

\section{Catholics Interpreting the Prophecies}

Regrettably, the veritable "explosion of scholarly writing on apocalyptic themes" in recent decades, with its concomitant eclipse of an older habit of disdainful categorisation of those who have embraced apocalyptic beliefs, ${ }^{1}$

1. Douglas H. Shantz, "Millennialism and Apocalypticism in Recent Historical Scholarship," in Prisoners of Hope? Aspects of Evangelical Millennialism in Britain and Ireland, 1800-1880, edited by Crawford Gribben and Timothy F. C. Stunt (Bletchley: Paternoster Press, 2004), 20 and 24-37.

Cadoc Leighton is an Associate Professor of European History at Bilkent University, Ankara, Turkey. 
appears to have created very few echoes in the study of nineteenth-century Catholic England. The neglect is understandable: an abundance of primary sources is not at once apparent and slight probing is discouraging. English Protestantism's extensive and intellectually developed apocalyptic category of religious literature, participating in an old and esteemed theological and exegetical tradition, but allowing widespread popular reception, appears at first to lack anything but the most undeveloped Catholic counterpart. The very existence of such a body of Protestant writings, which were, with few exceptions, founded in Luther's discovery of Antichrist in the essential constitution of Catholicism, inclined Catholics to confine themselves merely to refuting their assailants. If Catholics went beyond this and adopted the practices and concepts of Protestant students of the prophetic scriptures to serve their own purposes, they were discouraged. Thus, when the Dublin Review felt called upon, in 1855, to notice a work of the distinguished convert, Ambrose Phillipps, offering a scriptural interpretation which disclosed impending momentous events, its reviewer, the Irish barrister George Abraham, granted that such speculation was legitimate; however, he was not only dismissive of Phillipps' exegesis, but suggested that those who ventured into the area of unfulfilled prophecy might expect to be held up to ridicule. ${ }^{2}$ Such scornful responses conveniently allowed enlightened reprobation of what could be designated as religious fanaticism to serve as rhetoric against an anti-Catholic phenomenon. Phillipps' work, despite its zealously Catholic purpose, did indeed bear the external appearance of Protestant writings, with which he engaged. ${ }^{3} \mathrm{He}$ adopted their historicist interpretation of the Book of the Apocalypse $;^{4}$ spoke of immanent dates, a practice the Church's teachers judged temerarious; and he was propounding millenarianism, ${ }^{5}$ which they had, at best, regarded with suspicion since the era of the Reformation. ${ }^{6}$

Still, some did give cautious approval to Phillipps' views. One of the best known spiritual writers of the later nineteenth century, Giovanni Battista Pagani, then in charge of the Rosminian mission in England and later Rosmini's successor as provost-general of his institute, confessed that, at first, he found Phillipps' apocalyptic theory "rather strange"; but he was prepared to

\section{Dublin Review 38, no. 76 (June 1855): 424-42.}

3. Ambrose Lisle Phillipps [afterwards, Phillipps de Lisle], Mahometanism in its Relation to Prophecy or an Inquiry into the Prophecies concerning Antichrist (London: Charles Dolman, 1855), at, for example, $x-x i, 136-38,191-93$ and 257-65.

4. The term "historicist" in this context indicates an interpretation of the prophetic parts of scripture, notably the books of Daniel and the Apocalypse, which extends their reference to the entire period of history from their composition to the second coming of Christ. The Catholic exegetical tradition had generally preferred "preterist" and "futurist" interpretations. These confine the books' reference to the periods of the early history of the Church and its last days before the second coming of Christ respectively, and give much less opportunity for precise predictions of immediate fulfilment, since they do not provide indication of the intervening period's events or duration. See Kenneth G. C. Newport, Apocalypse and Millennnium: Studies in Biblical Eisegesis (Cambridge: Cambridge University Press, 2000), ch. 1.

5. Phillipps, Mahometanism, 211-15.

6. Bernard McGinn, "Forms of Catholic Millenarianism: a Brief Overview," in Catholic Millenarianism: From Savonarola to the Abbé Gregoire, ed. Karl A. Kottman, vol. 2, Millenarianism and Messianism in Early Modern European Culture, International Archives of the History of Ideas (Dordrecht: Kluwer Academic Publishers, 2001), 8-11. 
endorse it in the course of a more conventional, systematic work on eschatology, citing the views of the Ultramontane ecclesiastical historian, René Rohrbacher, in support. ${ }^{7}$ Interest and appreciation there was, but the work was hardly widely read. Gladstone, taking time to read it at the end of 1876 (after the publication of his Bulgarian Atrocities), recorded the acceptability of its central exegetical argument, identifying Antichrist with Islam, ${ }^{8}$ but Gladstone, like Pagani, had become acquainted with the book because of his personal acquaintance with Phillipps.

Much more important to note is that a work comparable to Phillipps', in its adoption of an historicist approach and its concern with contemporary history, had long enjoyed very widespread acceptance by English-speaking Catholics. This was Bishop Charles Walmesley's General History of the Christian Church, first published in 1771 under the pseudonym of "Signor Pastorini." It was translated into all the major European languages and reprinted often on both sides of the Atlantic for almost a century. As the evil that had been perceived by the bishop at the height of the French Enlightenment imposed itself on the mind of the whole Church in the form of the persecutions of the Revolutionary era and the enduring afflictions of the nineteenth century, the need among Catholics for an understanding of the times, and thus Walmesley's potential readership, grew. His historicist interpretation of the Book of the Apocalypse, with explicit rejection of a normative Catholic preterist tradition of exegesis, to be consulted in the pages of Bossuet and Antoine Calmet, was clearly not in itself a barrier to reception, though Walmesley was careful to present his work as standing in a solidly Catholic tradition of exegesis. ${ }^{9}$

In Ireland, the bishop acquired a reputation - enduring even among presentday historians - of preaching millennialism; but this was quite unwarranted. In his adoption of the venerable tradition of dividing history into seven ages, he located his own lifetime towards the end of the fifth of these and predicted, in his interpretation of Apoc. 16:10, that "the realm of the Reformation" would suffer the anger of God before it was concluded. This, however, was certainly not to usher in the Millennium. The sixth age was that of the greatest trial. ${ }^{10}$ During the agrarian disturbances in the southern counties of Ireland in the early 1820 s "brief extracts from the speculations in Pastorini's tome ... were distributed by the thousands." Their enthusiastic reception no doubt had much to do with the continuing existence of older beliefs in Catholic deliverance, associated, in the eighteenth century, with the tradition of aisling poetry. ${ }^{11}$

7. John Baptist Pagani, The End of the World: or The Second Coming of Our Lord and Saviour Jesus Christ (London: Charles Dolman, 1855), 70-71 and 290-301.

8. Edmund S. Purcell and Edwin de Lisle, Life and Letters of Ambrose Phillipps de Lisle (London: Macmillan, 1900), 2: 99 and 166-67.

9. Geoffrey Scott, “'The Times are Fast Approaching:' Bishop Charles Walmesley OSB (1722-1797) as prophet," Journal of Ecclesiastical History 36, no. 4 (1985): 590-604.

10. Sig[nor] Pastorini, The General History of the Christian Church, from Her Birth to Her Final Triumphant States in Heaven: Chiefly Deduced from the Apocalypse of St John the Apostle and Evangelist ([London]: n.p., 1771), 268 and 526.

11. James S. Donnelly, Jr., "Pastorini and Captain Rock: Millenarianism and Sectarianism in the Rockite Movement of 1821-4," in Irish Peasants: Violence and Political Unrest 1780-1914, edited 
In general, however, in Ireland as elsewhere, Walmesley was regarded as a respectable Catholic exegete, whose work had received episcopal commendation, notably from the popular English vicar apostolic, John Milner, over whose substantial and able history writing he appears to have exercised notable influence. $^{12}$

Walmesley, in claiming to stand in a Catholic scholarly tradition, in giving no conscious encouragement to millenarian belief and, again unlike Phillipps, in being notably imprecise about dates, had done a good deal to make his General History acceptable. However, it was not, despite its popularity, a forerunner in the expression of Catholic apocalyptic in the century after its publication. Among divines, always inclined to restrict themselves to "approved writers," there was the strength of the existing Catholic exegetical tradition to be considered. The alternative offered by Pastorini did seem to echo a Protestant "fanaticism" and liable to nurture, as Irish events had shown, popular religious sentiment of an undesirable and even dangerous kind. In brief, works like the General History were much less than satisfactory vehicles for the expression of Catholic apocalyptic beliefs. The form adopted by Phillipps or, later, his son, Edwin ${ }^{13}$ make the disregard of their contributions quite understandable.

Understandable too is the popularity of the General History. There were, after all, powerful impulses towards the development of apocalyptic beliefs among nineteenth-century English-speaking Catholics, as among their co-religionists on the European mainland, where the presence of such beliefs has received comment, in speaking of the phenomenon of Marian apparitions for example. ${ }^{14}$ Everywhere Catholics perceived the danger created by secular beliefs, pre-eminently expressing themselves in power-seeking political ideologies. This, by reaction, provided the foundation of much that is now commonly placed by historians under the singularly uninformative heading of the "New Catholicism." 15 This Catholic perception, constructed in the light of an extended historical vision of the menace, came to constitute the first element in that "divinely predetermined pattern of crisis - judgment — vindication," which has been seen as constantly characteristic of apocalyptic thought. ${ }^{16}$ That such thought manifested itself pervasively in what many English-speaking

by Samuel Clark and James S. Donnelly, Jr. (Manchester: Manchester University Press, 1983), 117-18.

12. Cadoc Leighton, "John Milner, History and Ultramontanism," Archivium Hibernicum 63 (2010): 348 n.11, and 368-72.

13. Edwin [Phillipps] de Lisle translated and published a German work, which clearly stood in the tradition of the seventeenth-century visionary Bartholomew Holzhauser. See A Comparison between the History of the Church and the Prophecies of the Apocalypse (London: Burns and Oates, 1874).

14. See, for example, Sandra L. Zimdars-Swartz, Encountering Mary: from La Salette to Medjugorje (Princeton, NJ: Princeton University Press, 1991), chs 4-7.

15. For exemplification of the use of the term "New Catholicism," see Christopher Clark, "The New Catholicism and the European Culture Wars" in Culture Wars: Secular-Catholic Conflict in Nineteenth-Century Europe, chap. 1, edited by Christopher Clark and Wolfram Kaiser (Cambridge: Cambridge University Press, 2003), 11-46.

16. Bernard McGinn, Apocalypticism in the Western Tradition (Aldershot: Variorum, 1994), first arabic pagination, $10-11$. 
Catholics wrote, ${ }^{17}$ it is a purpose of the present study to illustrate, though its character too, if its presence is to be noted, should be spoken about.

Precisely because this thought was pervasive, an attempt to locate sources requires a restricted approach, with attention to certain categories of related and even ostensibly unrelated subject matter. The need for attention to the latter categories may be briefly illustrated. A little over a year before the Dublin Review's publication of its criticism of Phillipps' book, the same journal published a long reflection, entitled "Russia and Turkey," on Newman's Lectures on the History of the Turks, by the barrister and writer on legal matters William Finlason - one of Father Faber's converts and, like George Abraham, a trusted contributor. Ostensibly, the piece was a consideration of historical topics, with political comment, occasioned by the looming declaration of war on Russia. The author did, though, declare that it was intended to stand among "religious views of the question." Indeed it did and might well be labelled as millenarian, though the millennium of the Book of the Apocalypse was not mentioned. In its comment on the coming war, it called instead for a renewal of crusade against Islam, possessed by the spirit of Antichrist, as were Protestantism and French Gallicanism, by virtue of their common assertion of secular power. The historical content of the article, supported by reference to nonbiblical prophecy, was intended to allow a prediction of "the destiny of Russia, the fate of Turkey, and the result to Christianity." Finlason's conclusion was that "Turkey must be absorbed by Russia, and that Russia must be re-absorbed in Catholic unity. The vastness of the prospect thus opened" encompassed "the Catholic religion spreading its benign sway - the Holy See exercising its Apostolic jurisdiction" over the formerly schismatic and Ottoman territories. It was thus "impossible not to see that the powers of Antichrist all over Asia would be shaken, and that India and China would not long be able to resist the progress of the faith." ${ }^{18}$ Not merely in its - albeit less than explicit millenarianism and in its identification of Antichrist with Islam, but even in its perception of the human instrument of his defeat, was Finlason's view one with that of Phillipps, who had cast the tsar as the Book of Daniel's "King of the North" and "could never persuade himself that any Russian victory . . . was not an advance of the Kingdom of Christ." 19 In brief, historicist, millenarian apocalyptic thought might be presented as a journalistic commentary on political affairs and be well received, while the same or very similar thought about both apocalyptic and contemporary affairs - when presented as biblical exegesis was likely to be greeted in a tone certainly dismissive, perhaps even abusive.

17. A study of Thomas Allies, one of the most celebrated of the Oxford converts in his day, offers a description of this nineteenth-century Catholic interpretation of history, and draws attention both to its prevalence and the difficulties involved in articulating it in England. See C. D. A. Leighton, "Thomas Allies, John Henry Newman and Providentialist History," History of European Ideas 38, no. 2 (2012): 248-65, pt. 4 . Allies, it may be noted in passing, was well acquainted with Faber, whose penitent he was.

18. Dublin Review 36, no. 71 (March 1855): 79-165. See esp. 80-95.

19. Purcell and de Lisle, Phillipps de Lisle, 2: 147. 


\section{Father Faber as a Guide}

It may well be that nineteenth-century Catholic treatments of contemporary international politics and, more so, historical writings, constitute a useful source for the study of apocalyptic. The present study has preferred to turn to a less obvious source: devotional and spiritual writing. For the further choice of that which came from the pen of Frederick Faber, little justification need be offered. The extent of his popularity - "something unprecedented in English Catholic literature," as a fellow Oratorian remarked ${ }^{20}$ — reveals a harmony with the popular Catholic mind of his period, which one concerned with it should not overlook. His works were enthusiastically received in the British Isles, in America, and, in numerous translations, on the European mainland, and were accorded a very marked degree of ecclesiastical approval. ${ }^{21}$ Moreover, the fundamental purpose that directed his labours as a writer reveals him as pre-eminently typical of his age. Taking his lead from those whose "handbooks and manuals have popularised astronomy, geology, and other physical sciences," he sought "to popularise certain portions of the science of theology," and in so doing render the practice of a spiritual life accessible and attractive to a wide lay public. ${ }^{22}$ Such accommodation to popular inclinations earned the author some opprobrium among the more rigorous. ${ }^{23}$ Faber's vocation as a writer, then, appears as particularly in tune with the fundamental characteristic attributed to the New Catholicism, of being shaped by popular Catholic needs and dispositions, as the Church grew increasingly estranged from governing and other elites. With regard to examining Faber as a source for the study of apocalyptic, it has at least been acknowledged by a recent study that "[ $t]$ he expectation of the end of the world [was] important in ... [Faber's] later writings." ${ }^{24}$ However, the matter has hardly been explored. The present article intends to make clear that such exploration is worthwhile.

Faber, in treating of eschatological matters, did not diverge, in the manner of Walmesley and Phillipps, from the interpretations of the prophetic texts offered by those he and his contemporaries recognised as approved Catholic divines. Faber cannot be classified as an historicist: he never essayed treatments of history which allowed his readers or hearers to place themselves with any precision or certainty in relation to its final events. The protagonist of the Protestant historicist drama that generally allowed such insight, a named Antichrist, was absent from Faber's writings. Antichrist could not be named, as the brief reign of this "king — his kingdom in visible antagonism to the kingdom of Christ" - lay veiled in futurity. Nor was there an earthly millennium to be

20. Rev. W[illiam] A[ntony] Hutchison to Msgr [George] Talbot, 27 July 1856, Wiseman Papers, W3/52, f50r, Archives of the Archdiocese of Westminster.

21. Ronald Chapman, Father Faber (London: Burns and Oates: 1961), 305. This remains the standard biography.

22. Frederick William Faber, The Blessed Sacrament, or The Works \& Ways of God, 3rd ed. (London: Burns and Oates; New York: Benziger Brothers, 1861), vii.

23. Faber to Henry Fitzalan-Howard, Earl of Arundel and Surrey, 2 January 1854, quoted in John Edward Bowden, The Life and Letters of Frederick William Faber, D.D., priest of the Oratory of St. Philip Neri, 2nd ed. (London: Burns and Oates, [1869]), 376-77.

24. Melissa J. Wilkinson, Frederick William Faber: a great servant of God (Leominster: Gracewing, 2007), 207. 
anticipated, either soon or late, either before or after the Second Advent. ${ }^{25}$ In brief, Faber was decidedly in the mainstream of Catholic apocalyptic thought, without any tendency to the historicist and millenarian views that commonly evinced manifest reserve or even hostility among his co-religionists. He was certainly in harmony with his own immediate ecclesiastical environment. Newman, for example, had already in the period before his conversion made clear his adherence to Catholic preterism and futurism: the prophecies which were taken to refer to a coming millennium had already been fulfilled literally, and the three and a half years of the reign of Antichrist lay at a future date that was not to be known. ${ }^{26}$ Christopher Dawson, most perceptively and with a justified emphasis, spoke of the need to apprehend "[t]he apocalyptic spirit" which shaped the thought and character of the early Tractarian movement. ${ }^{27}$ However, if this spirit is sought among its converts, either while they remained Anglican, or afterwards, it should at once be noted that it manifested itself in forms which displayed a very marked distance from both the methods and content of the scriptural interpretation which nourished the apocalyptic convictions of their Protestant contemporaries.

Indeed, Catholic apocalyptic differed radically from its Protestant counterpart - in literary form, in content and in methods of arriving at apocalyptic belief, such as attention to non-biblical prophecy, including that discerned in contemporary apparitions. Thus, when the Catholic phenomenon is brought within the field of the investigator, it seems best to turn to the most general themes in scholarly use as an aid to the organisation of thought. Such is scholarly industry, that these are numerous. In reading Faber, those acquainted with them will find them frequently evoked. Thus, for example, a linear view of history, in which history "and hence time, are simply an interlude between a prehistory when there was no time, and the 'posthistoric' kingdom of heaven which again will be timeless, ${ }^{28}$ is recurrently expressed in Faber. It is, indeed, the explicit subject matter of extended meditation, as in his Precious Blood, where salvation history is depicted at length as a procession from "the unchanging peace of awful sanctity which is the life and joy of God," that will return, beyond the Judgement, to its origin. ${ }^{29}$ However, whatever themes may be present, that of an apocalyptic crisis, giving historical and supernatural meaning to the present afflictions of a community, adverted to above as a key characteristic of apocalyptic thought, has been found in the present reading of Faber to so permeate his thought that it is impossible to disregard. Further,

\footnotetext{
25. Frederick William Faber, Notes on Doctrinal and Spiritual Subjects, edited by John E[dward] Bowden (London: Thomas Richardson and Son, 1866), 2: 16-17.

26. Colm McKeating, Eschatology in the Anglican Sermons of John Henry Newman (Lampeter: Mellen Research University Press, 1993), 28 and 166-67.

27. Christopher Dawson, "The Spirit of the Oxford Movement" and "Newman's Place in History" (London: St. Austin Press, 2001), 142-44.

28. Andrew Fear, "Orosius and Escaping from the Dance of Doom," in Historiae Mundi: Studies in Universal Historiography, edited by Peter Liddel and Andrew Fear (London: Duckworth, 2010), 178.

29. Frederick William Faber, The Precious Blood: or the Price of Our Salvation, new ed. (Philadelphia, PA: Peter Reilly, 1959; reprint, Rockford, IL: Tan Books, 1978), ch. 4. (Page citations below are to the reprint edition.)
} 
attention to this theme has the merit for an historical study, of keeping Faber constantly within his temporal environment. The remaining parts of this study therefore, turn to what Faber judged to be present intimations of the advent of Antichrist. These were both manifestations of evil and of the divine aid given to resist it. They were either signs to be read typologically, to give increased knowledge of a more distant future, or as much more immediate warnings.

\section{The Work of Antichrist Revealed}

Faber's insistence on casting Antichrist - the formal, efficient, and final cause of the apocalyptic crisis - into an imprecise, though not necessarily distant future, by no means precluded historical reflection on him. Newman, in declared exposition of patristic teaching, surveyed history from the persecutions of Antiochus to those of the French Revolution to identify types and "shadows and forebodings," which would display the character of Antichrist and the "operating elements" in the circumstances of his future coming. ${ }^{30}$ Faber shared this mode of reflection, expressing it in the familiar piety that "He [Christ] seems to wish us always to be expecting his coming." ${ }^{31}$ However, his reflection appears to have been more temporally limited. At least, when setting forth his teaching in brief compass, while he indicated that he had considered the history of Islam, it was clearly the emergence of Protestantism and the French Revolution which he considered the most noteworthy anticipations of Antichrist. ${ }^{32}$ The pairing is hardly unusual. Catholics in general had long asserted that "the terrible principle of private judgement," issuing in Philosophism, had originated with the Reformation - and England, in particular, was not infrequently pointed to as illustrating the destructive intellectual and political consequences of embracing such a principle. ${ }^{33}$ If English Catholics, in general, prudently underemphasised the latter reflection, writers such as Bishop Milner constantly recurred to the former. A vision of modern European history as a progressive liberation from religious authority had become rather commonplace by the mid-nineteenth century, and the acceptance and transvaluation of this among Catholics was aided by the perception that the philosphe conspiracy which had brought about the French Revolution, was but part of a temporally greatly extended and supernatural phenomenon. Such a transvalued version of this commonplace nineteenth-century historiography ${ }^{34}$ - a perception of an apocalyptic crisis, which may simply be denoted "modernity" - was fundamental to Faber's thought and, indeed, devotional life, though not in an historiographical form.

To have adopted such a form would have amounted to a secularisation of thought that Faber deliberately rejected. Thus, in a denunciation of liberalism

30. Quoted from Newman in McKeating, Eschatology, 29.

31. Faber, "On the late French revolution," 1848, Sermon Notes, Faber Papers, Archives of the London Oratory, Brompton [hereafter A. L. Orat.].

32. Faber, Notes, 2: 16-18.

33. Darrin M. McMahon, Enemies of the Enlightenment: the French Counter-Enlightenment and the Making of Modernity (Oxford: Oxford University Press, 2001), 43-46 and 143-45.

34. Leighton, "John Milner," 351-52 and 355-56 and Leighton, "Thomas Allies," pt. 4. 
and revolution he refused to permit "matters of our salvation to be carried off into the field of history, of criticism, of philosophy, or of politics. There undoubted sins get new names ..." Liberalism was best understood when named as "the old sin of lawlessness." Revolution, similarly, might be brought to "mean one thing in history, and another thing in political philosophy," but enduringly it was "simply and undignifiedly a mortal sin." By insistence on such linguistic correction, it became possible to "discern in our own times many of those peculiar marks by which prophets, apostles, and our Divine Lord himself, characterize the days of Antichrist." ${ }^{35}$ In consequence, a listing of "modern heresies," to be combated as sins by the practice of virtue, devotion and asceticism, ${ }^{36}$ shunned historical specificity to juxtapose "German rationalism" and "French unbelief" with different forms of Protestantism as explanation for the "[g]eneral wicked and corrupt state of the world, and consequent wretchedness." 37

This commitment of Faber to a de-secularisation of language, by which phenomena of this period, political, social, and intellectual, were adverted to in the self-consciously change-resistant language of the preacher or religious teacher, was far from merely personal. Present-day readers of ecclesiastical declarations of the period, particularly those of the Holy See, have noted together with their apocalyptic imagery - that their "arguments were couched in abstractions and statements of principle," and that they lacked an "effort at differentiation" and at "engagement with an authentically historical sensibility." 38 It might be answered that contemporaries open to what they read may well have found in this ecclesiastical rhetoric perceptiveness and profundity, rather than lack of sophistication. In any case, Faber's own use of it may render it difficult for present-day readers to perceive the constituent elements of the apocalyptic crisis that he perceived. The variety of evils on which he placed emphasis in attempting description of the "spirit of the age" at various points in his life, when listed, ${ }^{39}$ or his characterisations of the world which the Christian has renounced, may aid to lessen the difficulty. Still, they cannot be said to make plain at once the extent to which his writings are directed by the possession of a clear apprehension of the character of a supernatural evil, which the present-day reader will most readily see as a transvalued version of nineteenth-century modernity's popular self-image.

It has been characteristic of much recent scholarly writing on the late eighteenth and nineteenth century's militant Catholicism to assert that a concept of modernity which excludes the phenomena with which it is

35. Frederick William Faber, Devotion to the Church, 2nd ed. (London: Richardson and Son, 1861), 15.

36. Faber's rule for Brothers of the Will of God (Wilfridians), [14 Feb. 1846], Faber Papers,

A. L. Orat. See especially the third chapter. This society, established by Faber immediately after his conversion, survived only until 1848, when Faber and its other members became Oratorians. See Chapman, Faber, ch. 8.

37. Faber, "Prospects of the $\mathrm{Ch}[\mathrm{urch}]$ in the present state of the world," Sermon Notes, Faber Papers, A. L. Orat.

38. Clark, "New Catholicism," 36-39.

39. Wilkinson, Faber, conveniently indexes its numerous references to Faber's treatment of the theme of the spirit of the age. 
concerned stands in need of revision. ${ }^{40}$ We may go further, with the suggestion of Darrin McMahon, that hostility to its manifestations at least contributed to the formation of the very concept of modernity, in offering the "first coherent portrait" of the Enlightenment. ${ }^{41}$ The nineteenth-century experience of conflict did much to refine and develop that Catholic portrait of the enemy, a process which was inevitably influenced by that enemy's own self-image. Various ideological strands created and sustained those bitter and seemingly unending nineteenth-century conflicts, most famously Germany's Kulturkampf, between states, ever increasingly extending their power and influence over their subjects, and Catholic institutions and populations. Political ideologies, often appropriately viewed as elaborations of the creeds of new, secular religions, ${ }^{42}$ were prominent. However, these ideologies, increasingly recruited in the service of states or even appearing to direct them, almost invariably identified themselves with more general secular beliefs in rationalism, now giving way to scientism, with its promises of technological benefits, and progress. As David Blackbourn remarks: "The Kultur . . . advocated in the Kulturkampf was materialist, technological, and scientific: the culture of the railway, the agricultural field-station, the brave new world of Progress." ${ }^{43}$ Faber's writings repeatedly take up the theme of the alienation of Christianity from the state and reveal, pervasively, a desire to combat secularisation of thought, to diminish the authority of science, and to show contemporary belief in progress to be hollow. It is chiefly these features which serve to mark Faber as an apocalyptic writer, or more precisely, one who perceived an apocalyptic crisis in a transvalued version of nineteenth-century modernity's own self-image.

That Faber was an apocalyptic writer of this stamp may speak of some of his origins as a spiritual writer. The evil he perceived was not a social one, manifested in that general irreligion in society or that decline in religious practice in the population, so frequently reflected upon among his fellow Victorians. With the most authoritative teachers of his Church, the evil he saw was a supernatural one, and thus profound and pervasive. One could but entreat the mercy of God by prayer, penance, and holiness of life. If the time of Antichrist had come, what was to be expected but mass apostasy? This was, Faber held, to overwhelm even the greater number of Catholics, who were to be brought now to labour for the grace of perseverance. ${ }^{44}$ If the age's evils constituted no more than yet another foreshadowing of Antichrist, there were

40. Thus Christopher Clark regards it as fundamental to the understanding of the New Catholicism to place it alongside secular political movements as "artefacts of political modernity." Clark, "New Catholicism," 13. In writing of the ideological origins of the nineteenth century's militant Catholic revival, McMahon considered himself to be contributing to "the history of modernity itself." McMahon, Enemies of the Enlightenment, 16. Studies of more limited phenomena have made use of the same perception. See, for example, Ruth Harris, Lourdes: Body and Spirit in the Secular Age (London: Penguin, 1999), 12.

41. McMahon, Enemies of the Enlightenment, 11, 28-32, and 192-195.

42. Michael Burleigh, Earthly Powers: Religion and Politics in Europe from the Enlightenment to the Great War, 2nd ed. (London: Harper Perennial, 2006).

43. David Blackbourn, Marpingen: Apparitions of the Virgin Mary in Nineteenth-Century Germany (New York: Alfred A. Knopf, 1994), 256.

44. Faber, Notes, 2: 337. 
hopes of great things. Yet their fulfilment also could come only by divine action. Faber could be fervently optimistic about the immanent conversion of England; but he insisted that the goal was to be attained by spiritual endeavour, undertaken in the knowledge that, humanly speaking, it was an impossible one. ${ }^{45}$

The word "modern" itself is habitually used in Faber's writings with reference to an enveloping Antichristianism and serves as a more specific term than others, notably "the world," which was better sanctioned by his commitment to traditional Christian discourse for the expression of reprobation. The world, as a contrivance of Satanic hostility to the Church and the Christian, ${ }^{46}$ was, of course, as old as humankind's fallen state: and it possessed numerous realisations. Thus, "the end of the world" could be described as constituted by "an irreconcilable complication of the Church and the world"; but the complication to which he adverted was already manifested, he suggested, by the Church's "incongruity with modern times," the product of "its hopeless attitude of resistance to the clamours of modern political philosophy and the genius of so-called progress." In ascetic and devotional practice, with which he himself was most concerned, what was to be commended, therefore, was that which best combated the penetration of "modern ways and modern thoughts and modern things." 47

A rather similar overlap in Faber's usage, between the "world" and the "state," is doubtless among the most obvious nineteenth-century specifications of his apocalyptic thought. If he could describe the ultimate conflict as occasioned "an irreconcilable complication of the Church and the world," he could also, at the conclusion of a series of Epiphany lectures given in 1851 that constituted the clearest statement of his apocalyptic beliefs, remind his hearers that Antichrist was to reign: "so the Church's last enemy is to be a kingdom, the consummation of the wickedness of all kingdoms; how significant!" 48 Indeed, at the beginning of the lectures, Faber had indicated the likeliness of this conclusion with his sketch of a history of the church as a preliminary to speaking of the foreshadowings of Antichrist's reign in its vicissitudes, and of Christ's ultimate triumph in its various "resurrections." 49 The survey found in the period of the "[m]elting away of the Roman Empire" the Church's "first victory over a state"; in the subsequent "[a]ge of heresies," the tendency of heretics to lean "towards the civil power"; and in the Middle Ages, the struggle of the Papacy "to secure freedom from states, and freedom to teach." The modern period of the Church's history presented an image of the simple and powerless, loyal to the Church, ruled by Christ, its sovereign, and thus "above nationalities ... [and] thus represented in prophecy as the enemy of empires -

45. Faber, Notes, 1: 355-80 and 2: 13-16

46. Faber, Notes, 2: 11.

47. F[rederick] W[illiam] Faber, introduction to The Month of Mary Conceived without Sin,

by A[uguste] Gratry (London: Thomas Richardson and Son, [1860?]), xvi-xix.

48. Faber, Notes, 2: 18.

49. Faber, Notes, 2: 5-8. 
highest and most mysterious of allegiances ..." ${ }^{50}$ Faber no doubt took delight in justifying traditional Protestant accusations of elevating loyalty to a foreign power above loyalty to the British state. The Catholics' "loyalty and patriotism [was directed] to the most ancient, the most godlike of all monarchies, the Holy Apostolic Roman Church." ${ }^{51}$ Yet the state tout court could hardly be identified as a manifestation of Antichrist. After all, if the Syllabus of Errors was to declare that "progress, liberalism, and modern civilisation" were incompatible with Christian belief, it also denied that "[t]he Church ought to be separated from the State, and the State from the Church." ${ }^{52}$ Faber himself held that it was desirable that the Church should possess at least "political influence" for the benefit of "weak and less generous ... souls," likely to be too concerned with "human respect." 53 Thus, in the central bulk of Faber's lectures, the "world" was the appellation given to the entity with which Church was engaged in apocalyptic struggle, "where war to the knife is proclaimed at once." ${ }^{54}$ And thus also, an undesirable descent into the secularised, and thus trivial and necessarily less condemnatory discourses of history or political philosophy, was avoided.

However much Faber was inclined to the use of more general and less secular language, it remained his duty to point to and illustrate the innumerable evils that cumulatively constituted the crisis he perceived. It is chiefly in his constant recurrence to the evils prevalent in his age, as he undertook to show the appropriateness of the ascetic and devotional practices he commended, that the permeation of his work by an apocalyptic perception of modernity is shown. The opening passages of The Creator and the Creature (1856) provide exemplification. Here the comprehensiveness of the term he introduces, "forgetfulness of God," is stated.

It has been in all ages the grand evil of the world: a forgetfulness so contrary to reason, and so opposed also to the daily evidence of the senses, that it can be accounted for on no other hypothesis than that of original sin and the mystery of the fall..$^{55}$

He made it clear, though, that his desire was to speak of the distinctively modern manifestations of this "old sin," as the chapter heading designated it. If there is no wish to avoid a de-sacralised language, his subject matter might be stated as the anthropocentrism of the Enlightenment, as it issued in secularisation of thought and activity. He was able to range over the manifestation of secularisation in the areas of politics, literature, and the physical sciences, ${ }^{56}$ but it is clear that it was these last which constituted the focus of his concern with contemporary secularisation. The physical sciences were denounced for their

50. Faber, Notes, 2: 3-4.

51. Faber, Blessed Sacrament, 25.

52. Quoted from the text of the Syllabus given in Roberto de Mattei, Blessed Pius IX (Leominster: Gracewing, 2004), 185 and 188.

53. F[rederick] Faber, An Essay on Catholic Home Missions (London: Thomas Richardson and Son, 1851), 24-5.

54. Faber, Notes, 2: 12.

55. Frederick William Faber, The Creator and the Creature: Or, the Wonders of Divine Love, Orchard Books (London: Burns and Oates, 1961), 4.

56. Faber, The Creator and the Creature, 9-11. 
assumption that creation - implied by them to be no more than that of a departed Deist divinity — was "the end of and answer to all things, just as the Most Holy Trinity is to a believer." ${ }^{57}$ In a work published in 1860 , Bethlehem, he noted the mutation of eighteenth-century rationalism — perceived as significant chiefly for the christological consequences of the extension of reason's judgement over revelation - into nineteenth-century scientism:

It can hardly be doubted that the battle-field of faith and unbelief is moving from the Incarnation to the mystery of Creation ... It is true that faith and unbelief are always fighting at all their points of contact; but the thick of the battle is now amidst the facts and difficulties of creation. ${ }^{58}$

Bethlehem retained its de-secularised mode of discourse by its form, a series of meditations on the Incarnation, and it was thus capable of being read as part of the older warfare. However, Faber offered as his text on the title page one from the book of Job: "Ecce Deus Magnus vincens scientiam nostram! ..." While this was certainly perennially appropriate for a reflection on the mystery of the Incarnation, its nineteenth-century reference is apparent in the work's content. Science could, of course, no more be regarded as an intrinsice malum than literature, political activity in general, or the state in particular. He himself was not at all averse to bringing knowledge gained, for example, from astronomy to serve his own rhetorical purposes. ${ }^{59}$ The negative character of contemporary science lay in its disregard of God's will and purposes for humanity and a consequent disordering of a true hierarchy of knowledge. It was a "lawless" pursuit of science that was condemned.

Adam fell in the lawless search after science. His sin was a traitorous attempt to force the divine wisdom to give up the secrets which it chose to conceal. He endeavoured to force his way through the beautiful marvels of God's own creation into the counsels of God. He made disloyal use of his science to increase that science in spite of God. He leagued with the mighty fallen intelligence of God's enemy, in order to learn what God had forbidden him to know. ${ }^{60}$

Amelioration of the consequences of this fundamental disorder lay in the regulation of the pursuit of knowledge by that truth which had been divinely revealed and interpreted under the Church's authority. Science was provided with and required an anchor in the theology it might usefully serve, ${ }^{61}$ since "theological truth..., rightly considered, is properly itself all truth." ${ }^{62}$ Elsewhere, Faber broadened his condemnation of contemporary human intellectual activity and spoke of the consequences of disregard of religious restraint in the pursuit and communication of knowledge. In speaking of the

57. Faber, The Creator and the Creature, 4-5.

58. Frederick William Faber, Bethlehem, new ed. (London: Burns and Oates; New York:

Benziger Brothers, n.d.), 278-79.

59. See, for example, Faber, Bethlehem, new ed., 275 or Faber, Precious Blood, 20-21.

60. Faber, Bethlehem, 25.

61. Faber, Bethlehem, 285-86.

62. Faber, Bethlehem, 295. 
disastrous tendencies he observed in contemporary society, he attacked that widespread diffusion of knowledge and refinement of which his contemporaries were so proud, in so far as it was unregulated by religious purpose, as worse in its effects than barbarism. It was but an instrument, lacking to the barbarian, which served but to propagate false beliefs and realise immoral desires, with immensely increased destructive consequences for others. ${ }^{63}$

In view of the content his contemporaries gave to the concept, progress could only be, for Faber, a belief to be contradicted and argued against. In truth, in surveying contemporary history, he saw not advance, but proof "that an entire century can go astray." ${ }^{64}$ The view was omnipresent in Faber's thought, though he did sometimes form, as he wrote, explicit rejections of contemporary concepts of progress. He insisted that the criteria of judgement of periods be the good of souls, and was able consequently to conclude that "[i]n substantial matters the ages are pretty much on a level with each other." ${ }^{\prime}$ To concede, on occasion, that his own age might be merely no better than others, rather than singularly deviant, was possible to one allowed that what he perceived and condemned might be merely more "prophecies, types and foreshadowings of the last age, the age of Antichrist," ${ }^{\prime 66}$ rather than the preparations for that figure's final and more true advent. In any case, it was tempting to assail the Anglican tradition of yielding authority to an historically reconstructed primitive age of Christianity and the ameliorative attitude to contemporary society - or millenarian belief, in the case of Ambrose Phillipps - expressed by adherence to medievalism.

Faber recorded his disapproval of "the disobedient and antiquarian worship of some pet past ages of the Church" in a lecture published in 1850, which contained another rejection of a contemporary notion of progress. Here he playfully removed and replaced its content, stating that he too had a decided "preference for Modern Times" over previous ages. The heralding sign of the modern age he described was found in the Council of Trent. Its chief characteristic was the increase of certain knowledge — by dogmatic definition. And this knowledge was diffused and applied - in the age's new devotional practices. That which was particularly gratifying in this modern era was the growth of Ultramontanism, manifesting a "fading away of nationalism from men's minds." In addition to the growth and increased application of knowledge and welcome political developments, the technological innovations of the age were praised, since "[r] ailways, and electric telegraphs, and steam-ships to the tropics, are the hand-maid of the modern papacy." ${ }^{67}$ His lecture left parody to point to the coming apocalyptic struggle of the Church. It was a great merit

63. Faber, Precious Blood, 53-54.

64. Frederick William Faber, Spiritual Conferences, 7th ed. (London: Burns and Oates; New York: Benziger Brothers, 1888), 350.

65. Faber, Precious Blood, 27. The thought was recurrent. See also his Spiritual Conferences,

333 and cf. his Devotion to the Church, 14.

66. Faber, Precious Blood, 15.

67. Frederick William Faber, The Spirit and Genius of St Philip Neri (London: Burns and Lambert, 1850), 45. 
of the modern age that the Church and the world (and particularly the state) had increasingly separated. The parting from worldly powers, he observed, strengthened the papacy, and thus united the Church and made it more certain in its faith. It was indeed stripped of worldly power, but stripped as an athlete prepared for a momentous struggle. "O look well upon her! the athlete of God in these turbulent and changeful days." ${ }^{\text {"68 }}$ Faber believed in a progress, for "[e]very age of the Church is ... more glorious than any of the age that have preceded it." But this was achieved "by its very vicissitudes." ${ }^{99}$ Progress was constituted by what prepared the Church for its final trial.

\section{Victrix over Antichrist}

The most important element in that progress - towards the final manifestation of Antichrist - in which Faber did believe, was undoubtedly the activity of the Blessed Virgin Mary and the increase in devotion to her. The present essay has asserted that apocalypticism was central to Faber's thought. The point should be combined with Wilkinson's perfectly accurate assertion that "Faber's spirituality is fundamentally Marian in character." 70 Such Marian apocalypticism is hardly remarkable. Phillipps reminded his readers of a belief, which he traced back to St John Damascene, in the pre-eminent role of Mary in the struggle against Antichrist, and went on to witness to an important element in that belief as it was manifested in the nineteenth century. He cited the assertion of Leonard of Port Maurice, who was to be canonised in 1867, that the definition of the doctrine of the Immaculate Conception would mark the beginning of the substantial fulfilment of apocalyptic prophecy. ${ }^{71}$ Phillipps was certainly right to claim that a union of apocalyptic and Marian thought was very old. To probe no further back, the late medieval period's constantly developing thought about Mary's roles both in salvation history and as patroness and protectress expressed itself frequently in comminatory visions, which spoke of afflictions that were like or were those of the last days. ${ }^{72}$ The woman of the 12 th chapter of the Book of the Apocalyse was increasingly depicted as the Immaculate Conception. ${ }^{73}$ The eighteenth century, notably (with regard to the developments of the following century), saw devotion to Mary appear as a weapon in the struggle against the Enlightenment. ${ }^{74}$ Also from the eighteenth century, there emerged the writings of Louis-Marie Grignion de Montfort, in particular his

\footnotetext{
68. Faber, The Spirit and Genius of St. Philip Neri, 75-76.

69. Faber, introduction to Month of Mary, v.

70. Wilkinson, Faber, 252.

71. Phillipps, Mahometanism, 269-70.

72. See, for example, William A. Christian, Apparitions in Late Medieval and Renaissance Spain (Princeton, NJ: Princeton University Press, 1981), 144-9 and Daniel E. Bornstein, The Bianchi of 1399: Popular Devotion in Late Medieval Italy (Ithaca, NY: Cornell University Press, 1993), 43-44.

73. John A. Marino, Becoming Neapolitan: Citizen Culture in Baroque Naples (Baltimore, MD: Johns Hopkins University Press, 2011), 143.

74. See, for example, Enrique Giménez López, "La Devócion a la Madre Santísima de la Luz: un aspecto de la represion del jesuitismo en la España de Carlos III," Revista de Historia Moderna: Anales de la Universidad de Alicante 15 (1996): 213-32.
} 
Traité de la vraie devotion à la sainte Vierge, the call of which to a demanding Marian devotion was motivated by intense anticipation of the closing events of history. ${ }^{75}$

The nineteenth century's apocalyptic Marianism was diverse in expression, but in Faber it was firmly rooted and remained clearly focused. Marian doctrine and devotion, he insisted and constantly illustrated, belonged to the "essence" rather than the "extent" of Catholicism. If the best known and most extended expression of his devotion, At the Foot of the Cross, dwelt on the earthly life of the Virgin, his discourse in general spoke of her as a cosmic figure, engaged in all the aspects of the Church's mission in history. ${ }^{76}$ Integral to the doctrine, practice and cosmic history of the Church, Mary could not be excluded from the consummation of that history. However, much that spoke to Faber's contemporaries of Mary's role in their gloomy times, such as the Marian apparitions of his day, which attracted considerable English attention, ${ }^{77}$ he passed by with little comment. Inevitably, with his co-religionists throughout the world, Faber directed his attention in the early 1850s to the theme of Mary's cosmic triumph over evil in her Immaculate Conception. With a perception of the history of his own age as dominated by the advance of evil — and the countering manifestations of the Virgin's power — he had no doubt that the Church's act of calling on that power in the proclamation of Ineffabilis Deus would "probably be the greatest event of the nineteenth century. It will be an epoch in the history of the world . .." ${ }^{\circ 78}$ However, it was pre-eminently and enduringly the teaching of Grignion de Montfort which manifested itself in Faber's Marian apocalypticism. His attraction to it is unsurprising. For de Montfort did not merely aid him in articulating his apocalyptic beliefs, but offered a comprehensive and indeed demanding spirituality, laced with attractive devotional practices, which responded to those beliefs. It was shortly after his conversion, "in the year 1846 or 1847, at St Wilfrid's," that he first became acquainted with a "master" who came "forward, like another St Vincent Ferrer, as if on the days bordering the Last Judgment." ${ }^{\text {"79 }}$ However, it was necessary for him to struggle until the year before his death, when he undertook the translation of the Vraie devotion,

75. Hilda Graef, Mary: a History of Doctrine and Devotion, rev. and updated ed. (Notre Dame, IN: Ave Maria Press, 2009), 321-25.

76. See, notably, his lectures of 1851, "Mary and the Modern Church" in Faber, Notes, 2: 32-52.

77. The staid and prudent Bishop Ullathorne, for example, showed considerable interest in the prophecy and secrets revealed to the seers of La Salette. See William Bernard Ullathorne, The Holy Mountain of La Salette: a Pilgrimage of the Year 1854 (London: Richardson and Son, 1854), chs 8 and 9 .

78. Frederick William Faber, An Explanation of the Doctrine and Definition of the Immaculate Conception: With a Meditation (London: C. Dolman, 1855), 3. See also the sermons preached by Faber in preparation for and on the feast of the Immaculate Conception in 1854 at the London Oratory, which was the central focus of the city's celebration of the papal declaration. Faber, Notes, 2: 403-13. Wilkinson claims that Faber perceived "difficulties inherent within the definition" and suggests that he lacked enthusiasm for it. However, she cites no sources to support this rather strange view. See Wilkinson, Faber, 147-48.

79. Frederick William Faber, translator's preface to A Treatise on the True Devotion to the Blessed Virgin, by Louis-Marie Grignon [sic] de Montfort (London: Burns and Lambert, 1863), $\mathrm{v}-\mathrm{vii}$. 
personally to embrace de Montfort's challenging spiritual guidance in its entirety. ${ }^{80}$

Still, even without this final submission, Faber could embrace de Montfort's vision in both his interior life and his teaching. Though he had previously spoken of the matter, ${ }^{81}$ his belief that the final age of tribulation was to be the identified as the age of Mary was most explicitly declared in a preface to a translation of a recent French devotional work. ${ }^{82}$ The increased visible presence of Mary in the Church's life, he contended, spoke of the Last Days and present afflictions called for increased Marian devotion. The assertion was developed, not in a theological way, but practically and with reference to England. The role of Mary in the struggle against Antichrist, and thus the Antichristian forces that prepared or typologically foreshadowed his coming, meant that Marian devotion assumed "a very peculiar importance" in England, where human communication - in the press, in literature, in language itself — had suffered a gross Antichristian corruption, so that the very air seemed "impregnated with its poison." Few passages of Faber display so clearly the extent of his alienation from the society which surrounded him, and remind the reader so sharply of an attitude commonly manifested in pre-millennialist discourse.$^{83} \mathrm{He}$ concluded, characteristically, by speaking of the prevailing evil as a means of sanctification. Mary would become ever more present to the faithful. Calling the Catalan preacher of the late fourteenth and early fifteenth century, St Vincent Ferrer, to support de Montfort (as he seems to have done frequently in his preaching), he repeated the Dominican's belief that the last days would see "saints of almost unparalleled grandeur, whose distinguishing characteristic will be their devouring zeal for Mary's honour." ${ }^{\text {"4 }}$ The preface to his own translation of the de Montfort's text, about which, he observed, there was "something inspired and supernatural," ${ }^{85}$ returned more briefly to these themes, speaking of the value of de Montfort's spirituality for individuals and again of its particular value in the insidiously hostile culture of England.

Faber's preaching of Montfortian doctrine and practice does not appear to have been particularly influential in his own day, but was unexceptionable among Catholics. It attracted the hostile attention of Pusey in his Eirenicon, but was defended by William Ward ${ }^{86}$ However, with the general increase in Marian devotion, interest in "le saint de la Vendée," where the proleptic fulfilment his apocalyptic prophecy and the efficacy of his missionary labours were

80. Bowden, Life and Letters, 467-68.

81. See, for example, the lecture course "Mary and the Modern Church" cited above in Note 76.

82. Faber, introduction to Month of Mary, ix-xiv.

83. Faber's fondness for imagery suggestive of such alienation is noteworthy. See, for example, his descriptions of priests carrying the Eucharistic host, surrounded by hostile crowds - of Londoners and American nativist rioters - identified with the world/state's persecution of the Church. Faber, Blessed Sacrament, 176-78.

84. Frederick William Faber, The Spirit of Father Faber, Apostle of London, Spiritual Classics of English Devotional Literature (London: Burns and Oates, 1914), iv.

85. Faber, preface to True Devotion, xi.

86. A Secular Priest [Alexander P. J. Cruikshank], Blessed Louis-Marie Grignon [sic] de Mont-

fort . . . and his Devotion (London: Art and Book Company; New York: Benziger Brothers, 1892),

1: i. 
witnessed to in martyrdom, was certainly growing, in England as elsewhere, before and after his beatification in 1888. And Faber's role as a propagator of his teaching was acknowledged. When Alexander Cruikshank published a translation of Louis-Joseph Dalin's life of de Montfort in 1870, he dedicated the work "To the Holy Memory of Father Frederick William Faber," whom he described as "the apostle of our Lady's Bondage in England," referring to a central point of the master's practical teaching. ${ }^{87}$ Somewhat later, de Montfort's prophetic character and Faber's preaching of his doctrine received authoritative approval from Bishop Herbert Vaughan of Salford, who immediately began to distribute copies of Faber's translation of the Vraie devotion to his clergy when elevated to the see of Westminster. ${ }^{88}$

\section{Conclusion}

This article was not undertaken solely for the not unworthy purpose of offering a fresh aid to the interpretation of Faber's writings. It has also been intended to advance a much neglected approach to thought about nineteenth- and indeed early twentieth-century Catholicism. The placing of a New Catholicism within the bounds of modernity, as perceived by present-day historians, may well be seen as commendable (and has indeed been made use of in the present study). However, to this approach should be added an empathetic understanding of nineteenth-century Catholicism's hostility to what it itself defined, denounced and struggled against as modernity. This is, at least, a necessary preliminary to approaching the conflicts which dominated so many aspects of the life of Europe and other parts of the world in the nineteenth century and beyond. The synthesising of the themes of Catholicism's struggle against what it identified as modernity and its much increased and sometimes apocalyptic Marianism, by means of giving particular attention to apocalyptic, seems very likely to advance the empathetic understanding required. The pursuit of apocalyptic among both Catholic elites and populations in the nineteenth century and later seems likely to give access to an area of fundamental importance to the thought of very many, explanatory of their disposition towards their social and political environment, though often rather concealed by virtue of both their own cautious attitudes and the contemptuous attitudes of secularist elites towards it. It is hoped that the present study of Father Faber has indicated the possibility of ending such concealment.

87. A Secular Priest [Alexander P. J. Cruikshank], Life and Select Writings of the Venerable... Louis-Marie Grignon [sic] de Montfort (London: Thomas Richardson, 1870), v-vi and xxvii. 88. See Vaughan's introductory material in Louis-Marie, Grignon [sic] de Montfort, A Treatise on the True Devotion to the Blessed Virgin, trans. Frederick W. Faber, 8th ed. (London: Burns and Oates; New York: Benziger Brothers, 1892). 